\title{
Knowledge, attitude, and behaviour of Turkish dentists regarding contamination and prevention of Hepatitis B, Hepatitis $\mathrm{C}$ and HIV infection
}

\author{
Merve Koseoglu*, Hande Toptan**, Selma Altindis*** \\ *Department of Prosthetic Dentistry, Faculty of Dentistry, Sakarya University, Turkey \\ **Department of Microbiology, Faculty of Medicine, Sakarya University, Turkey \\ ${ }^{* * *}$ Department of Health Administration, Faculty of Management, Sakarya University, Turkey
}

\begin{abstract}
Introduction: Dentists are at risk of Hepatitis B, Hepatitis C, and HIV infections in their professional practices. The purpose of this study was to determine the knowledge level, attitude, and behaviours of the Turkish dentists regarding contamination and prevention of Hepatitis B, Hepatitis C, and HIV infections. Methods: After receiving the required ethical and administrative approvals, a 33-item digital survey was applied within the context of the present study, and carried out amongst 58 dentists. Results: According to the results of this study, the knowledge level did not vary between different demographic features $(p>0.05)$. However, the dentists' attitude and behaviours were different. Post-exposure attitude towards Hepatitis B, Hepatitis C, and HIV infection did not vary between different demographic features $(p>0.05)$. Female dentists who received education regarding infectious diseases more often got health check in case of injury $(p<0.05)$. Female dentists felt more concerned than male dentists when they were treating infected patients, and they were more often using protective barriers $(p<0,05)$. Dentists who were working at the university hospital and public hospital mostly had their Hepatitis B vaccinations more often than private clinics, also, dentists in university hospitals more often reported prefer to treat infected patients $(p<0.05)$. Dentists who did not receive any education have reported that dental treatment of infected patients should be performed in specialised clinics $(p<0.05)$. Conclusion: The Turkish dentists' knowledge level, attitude, and behaviour were different. According to the findings of this study, efficacious education programs should be prepared for dentists to establish a positive attitude towards Hepatitis B, Hepatitis C, and HIV infected patients.
\end{abstract}

Keywords: Dentists, Turkish, Hepatitis B virus, Hepatitis C virus, HIV

P-ISSN 1979-0201, e-ISSN 2549-6212 Available from:http://jurnal.unpad.ac.id/pjd/article/view/19305

DOI: http://dx.doi.org/10.24198/pjd.vol30no3.19305

Submission: Aug 14, 2018; Accepted: Oct 09, 2018; Published online: Nov 30, 2018

Corresponding author: Merve Koseoglu, Department of Prosthetic Dentistry, Faculty of Dentistry, Sakarya University, Turkey Mithatpaşa mah, Adnan Menderes Cd. No:122/B, 54100 Adapazarı/Sakarya, Turkey. Phone: +902642954117; Email: mervekoseoglu89@gmail.com 


\section{INTRODUCTION}

The healthcare professionals are exposed to infectious agents as an inevitable result of their profession and work environment. ${ }^{1}$ Therefore, in dentistry, bloodborne pathogens such as; hepatitis $B$ virus, hepatitis $C$ virus, and HIV may be transmitted through direct or indirect contact with blood, saliva, skin, and oral secretion, contaminated instrument, device and surfaces, stab wounds, and air-water spray. ${ }^{2}$

The development of infection resulting from exposure to any contamination agent requires the presence of a pathogen with a sufficient amount and virulence, an appropriate route for transmission of this pathogen and a predisposing subject to infection. ${ }^{3}$ The target of the infection control methods is to prevent the development of infection by breaking one or more links to infection chain. ${ }^{3,4}$

All the dentists and dentistry students should apply universal standard precautions all patients regardless of estimated contamination status. ${ }^{5,6}$ Vaccination, use of personal protective equipment such as sterile face masks, gloves and spectacles and post-exposure prophylaxis are crucial in preventing infection. ${ }^{6-9}$

Oral health is an important part of general medical care in the hepatitis $B$ virus, hepatitis $C$ virus and HIV positive patients. ${ }^{10}$ Dentists may be concerned and reluctant because of risk for contamination while treating hepatitis B virus, hepatitis C virus and HIV positive patients. ${ }^{11}$ These concerns may be originating from the knowledge deficiency about these diseases in some dentists. ${ }^{11,12}$

In our country, several studies have evaluated the awareness level and behaviours of the dentists about some contagious diseases, ${ }^{13}$ exposure frequency to infection in dentists ${ }^{14}$ and use of personal protective equipment. ${ }^{15}$ However, there is no comprehensive study in the literature which analysed the exposure rate of the Turkish dentists to infection, their knowledge level about standard precaution and practices after exposure to hepatitis B virus, hepatitis $C$ virus, HIV infections, and their attitudes and behaviours in an integrated approach.

The purpose of this study was to determine the knowledge level, attitude, and behaviours of the Turkish dentists regarding contamination and prevention of Hepatitis B, Hepatitis C, and HIV infections. This study hypothesised that the knowledge level, attitude, and behaviour of the dentists might vary depending on age, gender, professional status, and experience level.

\section{METHODS}

This study was a descriptive study to analyse the evaluation of the dentists who were representing healthcare service in health facilities regarding hepatitis B virus, hepatitis C virus and HIV infections. The study was conducted with the participation of 58 dentists throughout Turkey between July-August 2018 after receiving the required ethical and administrative approvals. A 33-item digital survey created using literature data ${ }^{16-19}$ was applied. The dentists were requested to answer the survey questions individually and voluntarily.

The survey form was composed of the questions to analyze the demographic characteristics of the dentists (gender, age, province and medical facility where the dentist works, working tempo, academic degree, title, branch of the specialization), knowledge level, attitude and behavior about hepatitis B virus, hepatitis $C$ virus and HIV infections.

Statistical analysis was performed using SPSS 23.0 (SPSS Inc., Chicago, IL, USA). The analysis was performed using the Fisher test because the data were not normally distributed. Since some observations obtained for analysis were small (more than $20 \%$ of cells of $2 \times 2$ contingency tables had expected frequencies $<5$ ), Fisher's exact test was needed. ${ }^{20}$ Statistical significance was set at the $p$-value $<0.05$.

\section{RESULT}

According to the results of the study, $39.7 \%$ of surveyed dentists were male, and $60.3 \%$ were female. $50.9 \%$ of dentists were $23-29$ years old, $36.8 \%$ were $30-39$ years old, $10.5 \%$ were $40-49$ years old, and $1.8 \%$ were over than 50 years old. $51.7 \%$ of the dentists had $1-5$ years experience, $22.4 \%$ had $6-10$ years experience, $13.8 \%$ had $11-15$ years experience, $12.1 \%$ had over than 15 years experience. 
Table 1. Dentists' knowledge regarding contamination and prevention

\begin{tabular}{|c|c|}
\hline \multicolumn{2}{|c|}{$\begin{array}{c}\text { Dentists' knowledge regarding contamination and } \\
\text { prevention }\end{array}$} \\
\hline Questions & Number(\%) \\
\hline \multicolumn{2}{|c|}{ Can HIV transmit by saliva? } \\
\hline Yes & $15(26.3 \%)$ \\
\hline No & $36(63.2 \%)$ \\
\hline Hesitant & $6(10.5 \%)$ \\
\hline \multicolumn{2}{|c|}{ Can vaccination protect from Hepatitis $\mathrm{C}$ infections? } \\
\hline Yes & $5(8.6 \%)$ \\
\hline No & $52(89.7 \%)$ \\
\hline Hesitant & $1(1.7 \%)$ \\
\hline
\end{tabular}

According to the results of this study, $55 \%$ of the dentists were a general practitioner, 35\% were $\mathrm{PhD}$ dentist, $7 \%$ were an assistant professor and $3 \%$ were professors. $55 \%$ of dentists had no specialisation in any branch of dentistry whereas $19 \%$ were specialized in prosthodontics, $10 \%$ periodontology, $4 \%$ pediatric dentistry, $4 \%$ orthodontics, $5 \%$ endodontics, $5 \%$ restorative dentistry, $3 \%$ oral and maxillofacial surgery and $2 \%$ oral radiology.

Of the participant dentists, $41 \%$ were working in a public hospital, $33 \%$ were in a university hospital, $21 \%$ in private hospitals and $5 \%$ in private clinics. $47 \%$ of the dentists have reported that they treated less than 10 patients daily, $16 \%$ treated $11-20$ patients, $21 \%$ treated 21-30 patients, and 16\% treated over than 30 patients. It was also reported that $86 \%$ of surveyed dentists received training about clinical infections whereas $14 \%$ did not receive any education.

Dentists' knowledge regarding contamination and prevention is presented in Table 1. Knowledge levels didn't vary between different demographic features also between individuals who received or not received any education $(p>0.05)$.

Dentists' attitude regarding contamination and prevention is presented in Table 2. Exposure times varied between age, experience, specialisation $(p<0.05)$; whereas there wasn't a difference between gender, working place and working tempo $(p>0.05)$. Dentists who were 30-39 years old, working for over 5 years and specialised in a branch have reported that they mostly got contact with infected blood and saliva. Exposure
Table 2. Dentists' attitude about contamination and prevention

\begin{tabular}{|c|c|}
\hline \multicolumn{2}{|c|}{ Dentists' attitude about contamination and prevention } \\
\hline Questions & Number (\%) \\
\hline \multicolumn{2}{|c|}{$\begin{array}{l}\text { Have you ever got contact with patients' infected blood } \\
\text { and body fluids? }\end{array}$} \\
\hline Yes & $40(69 \%)$ \\
\hline No & $18(31 \%)$ \\
\hline \multicolumn{2}{|c|}{$\begin{array}{l}\text { If you've had contact with infected blood and body fluids } \\
\text { in the patient, which way was this contact? }\end{array}$} \\
\hline Injury by contaminated sharp objects & $22(50 \%)$ \\
\hline $\begin{array}{l}\text { Mucosal contact with contaminated body } \\
\text { fluid (a splash to eyes, mouth etc.) }\end{array}$ & $10(22.7 \%)$ \\
\hline Injury by the contaminated injector & $12(27.3 \%)$ \\
\hline \multicolumn{2}{|c|}{$\begin{array}{l}\text { How often have you experienced injury by sharp objects } \\
\text { within the recent year? }\end{array}$} \\
\hline None & $27(46.6 \%)$ \\
\hline 1-5 times & $26(44.8 \%)$ \\
\hline 5-10 times & $4(6.9 \%)$ \\
\hline$>10$ times & $1(1.7 \%)$ \\
\hline
\end{tabular}

How often have you experienced contamination of infected material to eyes, ears and an oral cavity within the recent one year?

\begin{tabular}{lc}
\hline None & $34(58.6 \%)$ \\
$1-5$ times & $16(27.6 \%)$ \\
$5-10$ times & $3(5.2 \%)$ \\
$>10$ times & $5(8.6 \%)$ \\
\hline
\end{tabular}

Have you consulted with a department when you have contact with infected blood and body fluids?

I have consulted the infectious diseases department and reported the injury

$28(63.6 \%)$

I haven't consulted any department

$13(29.5 \%)$

Other

$3(6.8 \%)$

Do you wash your wound site with soap and water and apply the antiseptic solution in the case of injury by sharp objects?

\begin{tabular}{lc}
\hline Every time & $43(74.1 \%)$ \\
Frequently & $10(17.2 \%)$ \\
Occasionally & $3(5.2 \%)$ \\
Never & $2(3.4 \%)$ \\
\hline
\end{tabular}

routes and post-exposure attitudes didn't vary between different demographic features $(p>0.05)$.

Participant dentists' behaviour regarding contamination and prevention of hepatitis B virus, hepatitis $C$ virus and HIV infections are presented in Table 3. Dentists who received education about the infectious disease and were female more often got health check in case of injury $(p<0.05)$. 
Table 3. Dentists' behaviour regarding contamination and prevention

\begin{tabular}{|c|c|}
\hline \multicolumn{2}{|c|}{$\begin{array}{c}\text { Dentists' behaviour regarding contamination and } \\
\text { prevention }\end{array}$} \\
\hline Questions & Number (\%) \\
\hline \multicolumn{2}{|c|}{$\begin{array}{l}\text { Do you have hepatitis B virus, hepatitis C virus, HIV tests } \\
\text { during routine health check examinations? }\end{array}$} \\
\hline Every time & $11(19 \%)$ \\
\hline Frequently & $17(29.3 \%)$ \\
\hline Occasionally & $22(37.9 \%)$ \\
\hline Never & s8 (13.8\%) \\
\hline \multicolumn{2}{|c|}{$\begin{array}{l}\text { Do you have hepatitis B virus, hepatitis C virus, HIV tests } \\
\text { during health check examination in case of exposure? }\end{array}$} \\
\hline Every time & $37(63.8 \%)$ \\
\hline Frequently & $11(19 \%)$ \\
\hline Occasionally & $7(12.1 \%)$ \\
\hline Never & $3(5.2 \%)$ \\
\hline \multicolumn{2}{|l|}{ Have you ever received a hepatitis B vaccine? } \\
\hline I have never vaccinated & $2(3.4 \%)$ \\
\hline I have incompletely vaccinated & $5(8.6 \%)$ \\
\hline $\begin{array}{l}\text { I have vaccinated completely/according to } \\
\text { Schedule }\end{array}$ & $51(87.9 \%)$ \\
\hline \multicolumn{2}{|c|}{$\begin{array}{l}\text { Do you question the medical history of hepatitis B virus, } \\
\text { hepatitis } C \text { virus and HIV prior to the dental treatments? }\end{array}$} \\
\hline & $35(60.3 \%)$ \\
\hline Frequently & $9(15.5 \%)$ \\
\hline Occasionally & $11(19 \%)$ \\
\hline Never & $3(5.2 \%)$ \\
\hline \multicolumn{2}{|c|}{ Every patient should be considered as potentially infected } \\
\hline Agree & $44(75.9 \%)$ \\
\hline Disagree & $8(13.8 \%)$ \\
\hline Hesitate & $6(10.3 \%)$ \\
\hline \multicolumn{2}{|c|}{$\begin{array}{l}\text { Blood-borne diseases should be screened in each patient } \\
\text { by testing blood prior to the dental treatments }\end{array}$} \\
\hline Agree & $31(53.4 \%)$ \\
\hline Disagree & $16(27.6 \%)$ \\
\hline Hesitate & 11 (19\%) \\
\hline
\end{tabular}

Dentists who were working at a university hospital and public hospital mostly had their Hepatitis $B$ vaccinations more often than private clinics $(p<$ 0.05 ). This is most probably because vaccination against hepatitis $B$ is mandatory in public and university hospitals in Turkey. ${ }^{21}$ Also, $22.2 \%$ of the dentists noted that they didn't know their antiHBs titer values while some dentists reported that their titer values ranged between 96 and 1000 .

The frequencies of questioning medical history before dental treatment weren't varied between different demographic features $(p>0.05)$.
Table 4. Dentists' attitude regarding infected patients

\begin{tabular}{|c|c|}
\hline \multicolumn{2}{|c|}{ Dentists' attitude regarding infected patients } \\
\hline Questions & Number (\%) \\
\hline \multicolumn{2}{|c|}{ lamconcernedaboutthepossibilityof infection inthepatient } \\
\hline Agree & $42(72.4 \%)$ \\
\hline Disagree & $12(20.7 \%)$ \\
\hline Hesitate & $4(6.9 \%)$ \\
\hline
\end{tabular}

I am concerned about risk for contamination of infection during treatment of the patients infected by hepatitis $B$ virus, hepatitis $C$ virus and HIV.

\begin{tabular}{lc}
\hline Agree & $47(81 \%)$ \\
Disagree & $9(15.5 \%)$ \\
Hesitate & $2(3.4 \%)$ \\
\hline
\end{tabular}

I prefer not to treat the patients infected by hepatitis B virus, hepatitis $\mathrm{C}$ virus and HIV if possible.

\begin{tabular}{lc}
\hline Agree & $10(17.5 \%)$ \\
Disagree & $38(66.7 \%)$ \\
Hesitate & $9(15.8 \%)$ \\
\hline
\end{tabular}

I will treat the patients infected by hepatitis Bvirus, hepatitis $C$ virus and HIV if the protective precautions are taken.

\begin{tabular}{lc}
\hline Agree & $53(91.4 \%)$ \\
Disagree & $1(1.7 \%)$ \\
Hesitate & $4(6.9 \%)$
\end{tabular}

Dental treatment of patients infected by hepatitis B virus, hepatitis $C$ virus and HIV should be performed in the specialised clinics.

\begin{tabular}{lc}
\hline Agree & $32(55.2 \%)$ \\
Disagree & $23(39.7 \%)$ \\
Hesitate & $3(5.2 \%)$ \\
\hline
\end{tabular}

However, female dentists more often consider each patient as potentially infected than male dentists $(p<0.05)$. Participant dentists who have received education were more considering each patient as potentially infected than dentists who did not receive education $(p<0.05)$. Furthermore, female dentist more often reported that a blood test should be applied to each patient prior to the treatment $(p<0.05)$.

Participant dentists' attitude regarding infected patients is presented in Table 4. Female dentists felt more concerned than male dentists ( $p$ $<0.05$ ). Dentists who work in university hospitals more often reported that they would prefer to treat infected patients $(p<0.05)$. Dentists who didn't receive an education have reported that dental treatment of infected patients should be performed in specialised clinics $(p<0.05)$.

Participant dentists' attitude regarding infection control protocols is presented in Table 
Table 5. Dentists' attitude regarding infection control protocols

\begin{tabular}{|c|c|}
\hline \multicolumn{2}{|c|}{ Dentists' attitude regarding infection control protocols } \\
\hline Questions & Number (\%) \\
\hline \multicolumn{2}{|c|}{$\begin{array}{l}\text { Universal standard protocols are adequate in achieving } \\
\text { infection control during dental treatment of the patients } \\
\text { infected by hepatitis B virus, hepatitis C virus and HIV }\end{array}$} \\
\hline Agree & $36(62.1 \%)$ \\
\hline Disagree & $6(10.3 \%)$ \\
\hline Hesitate & $16(27.6 \%)$ \\
\hline \multicolumn{2}{|c|}{$\begin{array}{l}\text { Infection control protocols in my clinic are adequate } \\
\text { in preventing cross-contamination of hepatitis B virus, } \\
\text { hepatitis } C \text { virus and HIV infections. }\end{array}$} \\
\hline Agree & $24(41.4 \%)$ \\
\hline Disagree & $20(34.5 \%)$ \\
\hline Hesitate & $14(24.1 \%)$ \\
\hline \multicolumn{2}{|c|}{$\begin{array}{l}\text { Protective barriers used during dental treatment such } \\
\text { as gloves, masks, spectacles and face shield adequately } \\
\text { protect from infectious agents }\end{array}$} \\
\hline Agree & $28(48.3 \%)$ \\
\hline Disagree & $12(20.7 \%)$ \\
\hline Hesitate & $18(31 \%)$ \\
\hline \multicolumn{2}{|c|}{ Do you use spectacles during dental treatment? } \\
\hline Every time & $23(39 \%)$ \\
\hline Frequently & $11(19 \%)$ \\
\hline Occasionally & $20(34 \%)$ \\
\hline Never & $5(8 \%)$ \\
\hline \multicolumn{2}{|c|}{ Do you use mask and gloves during dental treatment? } \\
\hline Every time & $55(95 \%)$ \\
\hline Frequently & $3(5 \%)$ \\
\hline Occasionally & 0 \\
\hline Never & 0 \\
\hline
\end{tabular}

5. Male dentists more often consider that personal protective barriers can protect themselves from infectious agents $(p<0.05)$. On the other hand, female dentists more often used protective barriers $(p<0.05)$.

\section{DISCUSSION}

Dentists and auxiliary personnel carry a higher risk for contamination of numerous bacteria and viruses than normal populations. Therefore, knowledge level, attitude and behaviours of the dentists about prevention and protection from the pathogens which contaminated with infected blood and other body fluids become progressively important concerning achieving infection control. ${ }^{7,13,22,23}$
The hypothesis of the study that knowledge level, attitudes and behaviours of the dentists may vary depending on age, gender, education, professional status and experience level was partially accepted. Knowledge levels of dentists weren't different ( $p>0.05)$. However, attitudes and behaviours varied between dentists. As a result of this study, dentists who received education about the infectious disease and were female more often got health check in case of injury ( $p<$ 0.05). Female dentists felt more concerned than male dentists when they were treating infected patients and they more often used protective barriers $(p<0.05)$. Dentists who were working at a university hospital and public hospital mostly had their Hepatitis B vaccinations more often than private clinics also dentists in university hospitals more often reported that they would prefer to treat infected patients $(p<0.05)$. Dentists who didn't receive an education have reported that dental treatment of infected patients should be performed in specialised clinics $(p<0.05)$.

Age, gender, professional facility, professional experience and data of the daily treated patient's number which were obtained from this study were different from the previous studies conducted in Turkey. ${ }^{13}, 15,24$ It was thought to be because of the individuals participating in this study were different from other studies. While our study was conducted across the country, other studies were only conducted in specific populations.

In a study, among Canadian dentists, it was stated that $79.2 \%$ of dentists had education about infection control in the last 2 years. ${ }^{17}$ In a study in Iran, $81.3 \%$ of dentists had a continuing education course in the last 2 years. ${ }^{25}$ In a study among Tehran dentists, it was stated that $\% 68.3$ of them never attended to continuing education courses. ${ }^{26}$ According to the results of this study, different from other studies, $86 \%$ of the dentists received training about clinical infections. It was thought that this difference was caused by the more frequent trainings about infection control in our country, especially in recent years.

In a study in Iran, it was stated that over $89 \%$ of dentists had chosen the correct answers about the transmission infections of HIV/AIDS, hepatitis $B$ virus and hepatitis $C$ virus. ${ }^{18}$ According to the results of this study, $76 \%$ of dentists had 
chosen the correct answers about hepatitis B virus, hepatitis $C$ virus and HIV infections. Aksoy et al. ${ }^{13}$ have determined in their study that $61.5 \%$ of the dentists questioned the contagious diseases in Turkey. In the literature, it was reported that $90 \%$ of the German dentists obtain from their patients a risk factor history for hepatitis $B$ and $C$, mostly by written means and mostly at the first visit. ${ }^{7}$ According to the results of the study among Brazilian dentists, $83.1 \%$ of reported that they question the patient's history of hepatitis. ${ }^{16} \mathrm{~A}$ study among dentists who works in private dental clinics in Jordan stated that $77 \%$ of dentists asked about the medical history of patients. ${ }^{27}$ In a study in Pakistan, $95 \%$ of dentists were surveyed about past medical history from the patients. ${ }^{28}$ According to data obtained from this study, similarly to Aksoy et al. ${ }^{13} 60 \%$ of the participant dentists reported that they were questioning the medical history of hepatitis B virus, hepatitis C virus and HIV.

All our study were aimed at measuring the level of knowledge, attitude and behaviour of the dentists about hepatitis $B$ virus, hepatitis $C$ virus and HIV. It was concluded that dentists had hesitations in treating infected patients. It is needed to increase the level of dentist's knowledge, attitude and behaviour regarding transmission routes and vaccination by appropriate training.

A study in India, it was stated that $93.5 \%$ of dentists agreed with the suggestion that all patients should be regarded as infectious and that precautions should be applied universally. ${ }^{29}$ According to a study in Iran, 95\% of dentists have reported that all patients should be considered potentially infectious. ${ }^{18}$ In a study in Pakistan, dentists have reported that $98.5 \%$ of them agreed on the screening of patients for hepatitis $B$ and $C$ prior to any treatment. ${ }^{28}$ According to the results of this study, different from Indian ${ }^{29}$, Iranian ${ }^{18}$ and Pakistani ${ }^{28}$ dentist, $75.9 \%$ of dentists agreed with that every patient should be considered as potentially infected. Additionally, in this study, $53.4 \%$ of dentists agreed with that blood-borne diseases should be screened in each patient by testing blood prior to dental treatments.

As a result of a study in Iran, it was stated that $92 \%$ of dentists were anxious about increasing transmission risk of HIV and hepatitis infections while treating them. ${ }^{18}$ According to the results of a study in Poland, $64 \%$ of the dentists were moderately apprehensive of being infected with $\mathrm{HIV}$, hepatitis $\mathrm{B}$ virus or hepatitis $C$ virus as a result of performing their job. ${ }^{19}$ In this study, $81 \%$ of dentists have reported that they were concerned about the risk for contamination of infection during treatment of the patients infected by hepatitis B virus, hepatitis C virus and HIV. Also, $72.4 \%$ of dentist stated that they would be concerned about the possibility of infections in the patients.

In a study among Persian dentists, it was stated that $\% 73$ of dentists, would prefer not to treat HIV-positive patients. ${ }^{18}$ In a study among Saudi dental professionals, it was stated that $89.8 \%$ of the surveyed dentists were unwilling to provide dental care for hepatitis B virusinfected patients. ${ }^{30}$ According to the results of a study among Jordanian clinicians, $45 \%$ of the dental practitioners were willing to provide care to a person infected with the hepatitis $B$ virus. ${ }^{31}$ In a study among Tehran dentists, it was stated that $55.6 \%$ of dentists were willing to treat a patient with hepatitis B virus, unconditionally or with conditions. ${ }^{25}$ In a study in Poland, it was stated that $25 \%$ of the dentists have refused to perform specific procedures in patients with known infections. ${ }^{19}$ According to the results of a study in Palestine, \%68 of dentists declined dental appointment requests from HIV positive patients whereas, $32 \%$ of the dentists refused appointments with hepatitis $B$ virus-infected patients. ${ }^{32}$

In this study, it was reported that, if it's possible, $66.7 \%$ of dentist would prefer not to treat the patients infected by hepatitis $B$ virus, hepatitis $C$ virus and HIV. However, $91.4 \%$ of dentists have reported that they would prefer to treat patients infected by hepatitis B virus, hepatitis $C$ virus and HIV if the protective precautions were taken.

According to the results of a study in Iran, $70 \%$ of dentists have reported that patients with HIV or hepatitis should receive dental treatment in specialised clinics. ${ }^{18}$ In the present study, $55.2 \%$ of dentists have reported that dental treatment of patients infected by hepatitis B virus, hepatitis $C$ virus and HIV should be performed in the specialised clinics.

According to a study in Iran, $52 \%$ of dentists have reported that infection control principles are adequate for the prevention of transmission of HIV and hepatitis. ${ }^{18}$ In this study, $62.1 \%$ of dentists thought that universal standard protocols 
were adequate in achieving infection control during dental treatment of the patients infected by hepatitis B virus, hepatitis C virus and HIV infections. While, $41.4 \%$ of dentist thought that infection control protocols in their clinic were adequate in preventing cross-contamination of hepatitis B virus, hepatitis C virus and HIV infections.

Bulut et al. ${ }^{15}$ have reported that $68.1 \%$ of the dentists have been regularly vaccinated whereas $17.6 \%$ haven't been regularly vaccinated in Turkey. In the literature, it was reported that over $90 \%$ of British ${ }^{33}, 73.9 \%$ of Brazilian ${ }^{16}, 74 \%$ of German ${ }^{7}$, $90.6 \%$ of Canadian ${ }^{17}, 94.5 \%$ of Saudi $^{30}$, $98 \%$ of Polish ${ }^{19}$ dentists had hepatitis B virus vaccination. In the present study, $88 \%$ of the dentists had Hepatitis B vaccinations by schedule/completely.

Routine infection health check examinations are important in preventing cross-contamination, as well. ${ }^{15} \mathrm{~A}$ study in Italy stated that $69 \%$ of dentist had hepatitis B virus serologic tests, $64.5 \%$ had hepatitis $C$ virus tests, and $57.4 \%$ had HIV tests in periodic controls. ${ }^{33}$ In this study, not similarly to Italian dentists, ${ }^{34} 19 \%$ of dentists every time had hepatitis B virus, hepatitis C virus, HIV tests during routine health check examinations.

Bulut et al. ${ }^{15}$ had reported in their study that $39.6 \%$ of the Turkish dentists used gloves, face masks, spectacles, patient scrubs and dentist scrubs when they were treating patients. In the literature, it was stated that $54 \%$ of German dentists always wore protective gloves, $58 \%$ wore protective eyeglasses, $50 \%$ always wore face mask. ${ }^{7}$ $96.3 \%$ of Brazilian dentists used mask, $97.8 \%$ used gloves, $50.4 \%$ used protective glasses. ${ }^{35} 98 \%$ of Italian dentists used gloves, 95\% used masks, and $94 \%$ used protective eyewear. ${ }^{34} 82.3 \%$ of Canadian dentists wore the face mask, $82.1 \%$ always wore protective eyewear/face shield, \%94.6 always use gloves. ${ }^{17}$

In this study, similarly to Bulut et al., ${ }^{15} 39 \%$ of the surveyed dentists always used protective spectacles. Also, $95 \%$ of dentists used sterile face masks/ gloves during dental treatments.

Kandemir et al. ${ }^{24}$ have stated that $69 \%$ of the dentists experienced percutaneous injury within the recent one year. $35.9 \%$ of dentist were exposed to at least 1 needlestick injury during the past 3 months in Egypt. ${ }^{36}$ In Jordan, $66.5 \%$ of dentists had needle-stick injury within the preceding 12 months, and $77.9 \%$ of them did not report the injury. ${ }^{37}$ In a study, $54.8 \%$ of Brazilian dentists had one accident, $23.8 \%$ had two accidents, $11.9 \%$ had three and $9.5 \%$ had four or more accidents and $31.1 \%$ of them have reported the injury in the preceding year. ${ }^{35} \mathrm{~A}$ study in Italy stated that $73 \%$ of dentists had needle stick and other injuries in the last 5 years. ${ }^{34} \mathrm{In}$ a study, German dentists stated that $61.7 \%$ of dentists had at least one needle stick injury in their professional life..$^{38}$ In a study, $60.4 \%$ of Polish dentists had needle puncture injury, $\% 54.7$ got contact through splashing on conjunctiva within 12 months preceding the survey. ${ }^{19}$

In the present study, similar to Kandemir et al. ${ }^{24} 69 \%$ of dentists got contact with patients' infected blood and saliva. 50\% of dentists got injured by contaminated sharp objects, $27.3 \%$ injured by the contaminated injector, $22.7 \%$ got mucosal contact with contaminated blood and saliva. $44.8 \%$ of them got injured by sharp objects 1-5 times within the recent one year. Also, $27.6 \%$ of them have experienced contamination of infected material to eyes etc. 1-5 times within the recent one year.

In a study, it was reported that $41.3 \%$ of dentists in Canada applied a post-exposure protocol for needlesticks/cuts injuries. ${ }^{17}$ According to another study among dentists from different regions of Canadia, 36\% to $70 \%$ of dentists had a post-exposure protocol. ${ }^{39}$ According to results of a study in Jordan, $77.9 \%$ of dentists who had needlestick injury did not report the injury. ${ }^{37}$ $31.1 \%$ of Brasilian dentists have reported their injuries in the preceding year. ${ }^{3}$ According to the results of a study among Italian dentists, $29.7 \%$ of them claimed to have written protocols to follow in case of accident. ${ }^{34}$

In this study, $63.6 \%$ of dentists have reported the injury and consulted the infectious diseases department after the exposure. Furthermore, $74.1 \%$ of dentists have reported that they washed their wound site with soap and water and applied the antiseptic solution in the case of injury by sharp objects.

\section{CONCLUSION}

Dentists frequently face a risk for contagious diseases such as hepatitis B virus, hepatitis C 
virus and HIV during dental treatments; but their knowledge levels, attitudes and behaviours regarding these infections are different. Efficacious training programs should be prepared for dentists to increase knowledge levels, establish positive attitudes and behaviours regarding hepatitis $B$, hepatitis C and HIV infected patients and to upgrade all of them to a standard level.

\section{REFERENCES}

1. Sepkowitz KA, Eisenberg L. Occupational deaths among healthcare workers. Emerg Infect Dis. 2005;11(7):1003-8. DOI: $10.3201 /$ eid1107.041038.

2. Kuhar DT, Henderson DK, Struble KA, Heneine W, Thomas V, Cheever LW, et al. Updated US Public Health Service guidelines for the management of occupational exposures to HIV and recommendations for postexposure prophylaxis. Infect Cont Hosp Epidemiol. 2013;34(9):874-93. DOI: 10.1086/672271.

3. Machado-Carvalhais HP, Martins TC, RamosJorge ML, Magela-Machado D, Paiva SM, Pordeus IA. Management of occupational blooodborne exposure in a dental teaching environment. J Dent Educ. 2007;71(10):1348-55.

4. Kotelchuck D, Murphy D, Younai F. Impact of underreporting on the management of occupational bloodborne exposures in a dental teaching environment. J Dent Educ. 2004;68(6):614-22.

5. De Souza RA, Namen FM, Galan J Jr., Vieira C, Sedano HO. Infection control measures among senior dental students in Rio de Janeiro State, Brazil. J Public Health Dent. 2006; 66(4): 2824. DOI: $10.1111 / j .1752-7325.2006 . t b 04084 . x$.

6. Gunson RN, Shouval D, Roggendorf $M$, Zaaijer $\mathrm{H}$, Nicholas $\mathrm{H}$, Holzmann $\mathrm{H}$, et al. Hepatitis $B$ virus (HBV) and hepatitis C virus (HCV) infections in health care workers (HCWs): guidelines for prevention of transmission of HBV and HCV from HCW to patients. J Clin Virol. 2003;27(3):213-30. DOI: 10.1016/S13866532(03)00087-8

7. Ammon A, Reichart PA, Pauli G, Petersen LR. Hepatitis $B$ and $C$ among Berlin dental personnel: incidence, risk factors, and effectiveness of barrier prevention measures. Epidemiol Infect. 2000;125(2):407-13.
8. Gounden YP, Moodley J. Exposure to human immunodeficiency virus among healthcare workers in South Africa. Int J Gynaecol Obstet 2000;69(3):265-70.

9. Chogle NL, Chogle MN, Divatia JV, Dasgupta D. Awareness of post-exposure prophylaxis guidelines against occupational exposure to HIV in a Mumbai hospital. Natl Med J India. 2002;15(2):69-72.

10. Rohn EJ, Sankar A, Hoelscher D, Luborsky $M$, Parise $M H$. How do social-psychological concerns impede the delivery of care to people with HIV? Issues for dental education. J Dent Educ. 2006;70(10):1038-42.

11. Brailo V, Pelivan I, Škaričić J, Vuletić $M$, Dulčić N, Cerjan-Letica G. Treating patients with HIV and Hepatitis $B$ and $C$ infections: Croatian dental students' knowledge, attitudes, and risk perceptions. J Dent Educ. 2011;75(8):1115-26.

12. Wiltshire AD, Ross MW, Brimlow DL. Empathic communication between dental professionals and persons living with HIV and AIDS. J Dent Educ. 2002;66(1):86-93.

13. Aksoy A, Arikan FB. Dentists Regarding The Infectious Diseases (AIDS, Hepatitis B, Tuberculosis, Influenza, Mumps) Awareness And Behavior. BEU J Sci. 2016;5(2):113-22.

14. Yilmaz MZ, Torun AC, Senturk F, Muglalı $M$, Ozkan N. Evaluation of the distribution of exposure to infection and prevention methods in dentistry according to professional experience and clinics. Abant Med J. 2015;4(1):33-40.

15. Bulut E, Bas B, Soykan S. The Evaluation of Sterilization, Disinfection and Infection Control in Private Dental Clinics. Ondokuzmayıs Univ Dis Hekim Fak Derg. 2013;14(2):21-5.

16. Resende VLS, Abreu MHG, Paiva SM, Teixeira $R$, Pordeus IA. Concerns regarding hepatitis $B$ vaccination and post-vaccination test among Brazilian dentists. Virol J. 2010;7(1):154.

17. McCarthy GM, Koval JJ, MacDonald JK. Compliance with recommended infection control procedures among Canadian dentists: results of a national survey. Am J Infect Control. 1999;27(5):377-84. DOI: 10.1016/ S0196-6553(99)70001-5.

18. Hamideh K, Shirin S, Parviz G. Knowledge, attitude and practice of dentists towards 
patients with HIV, Hepatitis B and Hepatitis C infections. Avicenna J Dent Res. 2014;6(1):2139. DOI: $10.17795 /$ ajdr-21348.

19. Garus-Pakowska A, Górajski M, Szatko F, Tchounwou PB. Knowledge and Attitudes of Dentists with Respect to the Risks of Blood-Borne Pathogens-A Cross-Sectional Study in Poland. Int J Environ Res Public Health. 2017;14(1):69-80. DOI: 10.3390/ ijerph14010069.

20. Kim HY. Statistical notes for clinical researchers: chi-squared test and Fisher's exact test. Restor Dent Endod. 2017;42(2):152-

5. DOI: $10.5395 /$ rde.2017.42.2.152

21. Selman E, Karahan ZC. Infection Risks for Healthcare Workers and Protection I: Infections Transmitted By Blood and Body Fluids. J Ankara Univ Facult Med. 2014;67(2):41-9.

22. Araujo MW, Andreana S. Risk and prevention of transmission of infectious diseases in dentistry. Quintessence Int. 2002;33(5):37682.

23. Carvalho P, Schinoni MI, Andrade J, Vasconcelos Rego MA, Marques P, Meyer R, et al. Hepatitis $B$ virus prevalence and vaccination response in health care workers and students at the Federal University of Bahia, Brazil. Ann Hepatol. 2012;11(3):330-7.

24. Kandemir S, Karatas S. Meslegini Surduren Dishekimlerinin Meslege Baglı Saglı Sikayetlerinin Belirlenmesi. Cumhuriyet Univ Dis Hek Fak Derg. 2001;4(1):41-6.

25. Khosravanifard B, Rakhshan V, Ghasemi M, Pakdel A, Baradaran-Eghbal S, Sheikholeslami $\mathrm{R}$, et al. Tehran dentists' self-reported knowledge and attitudes towards HIV/AIDS and observed willingness to treat simulated HIV-positive patients. East Mediterr Health J. 2012;18(9):928-34.

26. Khosravanifard B, Rakhshan V, Najafi Salehi L, Sherafat S. Tehran dentists' knowledge and attitudes towards hepatitis $B$ and their willingness to treat simulated hepatitis $B$ positive patients. East Mediterr Health J. 2014;20(8):498-507.

27. Al-Omari MA, Al-Dwairi ZN. Compliance with infection control programs in private dental clinics in Jordan. J Dent Educ. 2005;69(6):6938.

28. Batool A, Sherwani MUIK, Bano KA, Aasim M.
Knowledge, attitude and practices of dentists about Hepatitis B and C infection in Lahore. Pak J Med Res. 2012;51(3):93-6.

29. Singh BP, Khan SA, Agrawal N, Siddharth R, Kumar L. Current biomedical waste management practices and cross-infection control procedures of dentists in India. Int Dent J. 2012;62(3):111-6. DOI: 10.1111/j.1875595X.2011.00100.X

30. Khalil H. Willingness of Saudi dental professionals to treat Hepatitis B virus-infected patients. Niger J Clin Pract. 2015;18(2):24750. DOI: 10.4103/1119-3077.151053.

31. El-Maaytah MA, Jerjes W, Upile T, Patel BJ, Hammad OA, Odeh ND, et al. Willingness of Jordanian clinicians to treat a hepatitis B-infected patient. Quintessence Int. 2008;39(4):147-51.

32. Kateeb E, Amer R, Bajali M. Factors related to the willingness of Palestinian dentists to treat patients with blood-borne diseases. Int Dent J. 2015;65(2):103-9. DOI: 10.1111/idj.12138.

33. WhittleJG.Anaudit of thehepatitisBvaccination status of staff in general dental practices in Lancashire. Prim Dent J. 2003;10(1):27-9. DOI: 10.1308/135576103322504085

34. Veronesi L, Bonanini M, Dall'Aglio P, Pizzi $S$, Manfredi M, Tanzi ML. Health hazard evaluation in private dental practices: a survey in a province of northen Italy. Act Bio Med Ateneo Parmensis. 2004;75(1):50-5.

35. Bellissimo-Rodrigues WT, Bellissimo-Rodrigues F, Machado AA. Occupational exposure to biological fluids among a cohort of Brazilian dentists. Int Dent J. 2006;56(6):332-7. DOI: 10.1111/j.1875-595X.2006.tb00337.x.

36. Talaat M, Kandeel A, El-Shoubary W, Bodenschatz C, Khairy I, Oun S, et al. Occupational exposure to needlestick injuries and hepatitis $B$ vaccination coverage among health care workers in Egypt. Am J Infect Control. 2003;31(8):469-74. DOI: 10.1016/j. ajic.2003.03.003

37. Khader Y, Burgan S, Amarin Z. Self-reported needle-stick injuries among dentists in north Jordan. East Mediterr Health J. 2009;15(1):185-9.

38. Wicker S, Rabenau HF. Occupational exposures to bloodborne viruses among German dental professionals and students in a clinical setting. 
Padjadjaran Journal of Dentistry 2018;30(3):197-206.

Int Arch Occup Environ Health 2010;83(1):77-

83. DOI: $10.1007 / \mathrm{s} 00420-009-0452-3$

39. McCarthy GM, Koval JJ, John MA, MacDonald
JK. Infection control practices across Canada: do dentists follow the recommendations? J Can Dent Assoc. 1999;65(1):506-11. 